\title{
Users' Attitude and Satisfaction towards E-Bikes: A Study in Erode District
}

\author{
N. Sakthivel ${ }^{1 *}$ and S. Senthilkumar ${ }^{2}$ \\ 'Associate Professor and Research Supervisor, PG and Research Department of Commerce, \\ Gobi Arts and Science College (Autonomous), Gobichettipalayam, \\ Tamil Nadu, India; sakthivel_gasc@rediffmail.com \\ ${ }^{2}$ Placement Officer and Research Scholar, PG and Research Department of Commerce, \\ Gobi Arts and Science College (Autonomous), Gobichettipalayam, \\ Tamil Nadu, India; senthilklp@gmail.com
}

\begin{abstract}
Global warming is a major concern all over the world. There are several policies, promises and pledges to save environment. With the ever increasing emission of greenhouse gases, there is an increased fear of environment pollution at every step. With modern technology and innovation, transportation and communication have undergone a paradigm shift. Increased numbers of fossil-fuel dependent vehicles, not only add to greater level of pollution but are also leading to depletion of fuel resources. This has necessitated automobile companies to innovate motorized vehicles that get charged through electricity and do not depend on fossil fuels. This led to the expansion of eco-friendly initiatives and many automobile manufacturing companies have invested in bringing forth E-Bikes, known as Electric Bikes, which help people save a few bucks by reducing consumption of already spiraling fuel price, besides fighting global warming. E-Bikes are environment friendly as air and noise pollutions are much reduced. In this backdrop, an attempt has been made in this study to analyze users' attitude towards E-Bikes in Erode district of Tamil Nadu. The study has divulged that 'smooth driving' is the most influencing factor in the purchase decision of users; none of the socio-economic variables has any significant association with the satisfaction of e-bike users; and however, 'poor battery life' is the most significant problem faced by them.
\end{abstract}

Keywords: $\mathrm{CO}_{2}$ Emission, E-Bikes, Environment Friendly, Global Warming, Greenhouse Gases, Pollution

\section{Introduction}

Global warming is a major concern all over the world. There are several policies, promises and pledges to save environment. With the ever increasing emission of greenhouse gases, there is an increased fear of environment pollution at every step. With modern technology and innovation, transportation and communication have undergone a paradigm shift. Increased numbers of fossil-fuel dependent vehicles not only add to greater level of pollution but are also leading to depletion of fuel resources. This has triggered automobile companies to innovate motorized vehicles that get charged through electricity and do not depend on fossil fuels. This led to the expansion of eco-friendly initiatives and many automobile manufacturing companies have invested in bringing forth E-Bikes, known as Electric Bikes, which help people save a few bucks by reducing consumption of already spiraling fuel price, besides fighting global warming. Against this background, an attempt has been made in this study to analyze users' attitude towards E-Bikes in Erode district of Tamil Nadu.

\section{Review of Literature}

Yuvraj Bhatnagar ${ }^{1}$ concluded that to achieve higher market share for electric scooters, companies should focus

*Author for correspondence 
on trend and fashion, features and brand equity, value for money, engine power and advertisement. Sheela Srivastava ${ }^{2}$ analysed the customer perception on green brands of two wheelers and four wheelers and suggested the need for improved technology in their manufacturing. André Hackbarth $^{3}$ found that except refueling time, all vehicle attributes considered were highly statistically significant. Hausan $^{4}$ analysed the influences of environmental consciousness and attitudes towards transportation on electric vehicle purchase decisions.

\section{Objectives of the Study}

- To study the brand preference of E-Bike users.

- To identify the factors influencing the E-Bike users to select a particular brand of E-Bike.

- To study the influence of socio-economic characteristics on users' level of awareness towards E-Bikes.

- To examine the influence of socio-economic characteristics on users' level of satisfaction towards E-Bikes.

- To analyse the problems faced by the E-Bike users.

\section{Research Methodology}

\subsection{Sample Size and Sampling Design}

The present study is confined to Erode District. Erode district is one of the famous trade cities in Tamil Nadu. Two wheeler personal transports play a significant role in this district. This district is also not free from air pollution due to the emission of $\mathrm{CO}_{2}$ from gasoline two wheelers. It is widely accepted that the alternative to gasoline two wheelers is E-Bikes. The usage of E-Bikes in Erode district is much more modest in terms of sales among the other famous trade cities in Tamil Nadu. Hence, this district has been chosen for the present study. The sample size of the present study is 100 . For selecting 100 E-Bike users in Erode district, Snowball Sampling Technique has been applied. This technique has been employed due to the difficulty in accessing E-Bike users as there is no registration for E-Bike users.

According to this technique, an attempt has been made to identify one or more E-Bike users among the desired population and using the identified E-Bike users again, an attempt was made to find further E-Bike users and so on until the sample size is met. The E-Bike users have been identified through snowball sampling technique in the areas of Erode, Gobichettipalayam, Bavani, Sathyamangalam and Perundurai.

\subsection{Collection of Primary Data}

The present study is based on primary data. It is an empirical research based on the survey method. For collecting required primary data from the E-Bike users, well-structured and pre-tested interview schedule has been used.

\subsection{Tools for Data Analysis}

Chi-Square Analysis has been used to examine the influence of various variables on users' awareness and satisfaction levels towards E-Bikes. Garrett Ranking technique has been used to identify factors influencing the users to select a particular brand of E-Bike and the problems faced by the E-Bike Users and percentage analysis is also used for analyzing the primary data.

In the present study, six brands of E-Bike, which are familiar in study area, are considered for analyzing the brand preference of E-Bike Users. Table 1 shows that the majority of $56 \%$ of the sample E-Bike users have selected Hero Electric Bike in the study area.

For analyzing the factors influencing the E-Bike users in selecting a particular brand of E-Bike in the study area, ten factors as disclosed in Table 2 have been taken into consideration. It is inferred from Ranking Analysis that sample E-Bike users have ranked 'Smooth Driving' as first with a mean score of 55.18, 'Cost Effective' as second with a mean score of 54.62 and 'Style and Design' as third with a mean score of 54.5 followed by 'Brand Image, 'Warranty', 'Spare parts Availability', 'Speed, 'After Sales Service,' 'Pick up and Mileage. Hence, it can be concluded that the factorssmooth driving, cost effectiveness and style and design of E-Bike influence the users to select a particular brand of E-Bike.

\section{Users' Awareness and Satisfaction towards E-Bikes}

In order to examine the influence of socio-economic characteristics of E-Bike users on their level of awareness and

Table 1. Analysis and interpretation brand preference of e-bike users

\begin{tabular}{lcc}
\hline Brands & No. of respondents & $\%$ \\
\hline Hero Electric & 56 & 56 \\
BPG E-Bike & 14 & 14 \\
BSA Motors & 10 & 10 \\
TVS Electric & 8 & 8 \\
EKO E-Bike & 8 & 8 \\
Lectrix Bike & 4 & 4 \\
Total & 100 & 100 \\
\hline Source: Survey data & &
\end{tabular}

HuSS: International Journal of Research in Humanities and Social Sciences 
satisfaction towards various features of E-Bikes, the following null hypotheses were formulated and tested through Chi-square analysis at $5 \%$ level of significance:

$\mathrm{H}_{0}$ : Age, Gender, Marital Status, Educational Qualification, Occupation, Type of Family and Annual Income do not significantly influence their level of awareness and satisfaction towards various features of E-Bikes.
The results of the chi-square test have been presented in Table 3 and 4.

From Table 3, it is found that the calculated values for all the socio-economic characteristics considered are less than the table values at 5\% level of significance and the framed null hypotheses are accepted. Hence, it is concluded that there is no significant relationship between various

Table 2. Factors influencing the users to select a particular brand of e-bike: ranking analysis

\begin{tabular}{|c|c|c|c|c|c|c|c|c|c|c|c|c|}
\hline \multirow[t]{3}{*}{ Factors } & \multicolumn{10}{|c|}{ Rank } & \multirow[t]{3}{*}{ Mean Score } & \multirow[t]{3}{*}{ Rank } \\
\hline & 1 & 2 & 3 & 4 & 5 & 6 & 7 & 8 & 9 & 10 & & \\
\hline & 81 & 70 & 63 & 57 & 52 & 47 & 42 & 36 & 29 & 18 & & \\
\hline Cost Effective & 18 & 11 & 10 & 12 & 7 & 14 & 9 & 5 & 8 & 6 & 54.62 & II \\
\hline Smooth Driving & 11 & 15 & 12 & 16 & 10 & 13 & 9 & 7 & 2 & 5 & 55.18 & I \\
\hline Style and Design & 15 & 8 & 16 & 12 & 9 & 14 & 10 & 4 & 7 & 5 & 54.5 & III \\
\hline Brand Image & 12 & 10 & 14 & 13 & 12 & 10 & 8 & 7 & 9 & 5 & 53.28 & IV \\
\hline Warranty & 11 & 12 & 13 & 6 & 10 & 18 & 9 & 7 & 6 & 8 & 52.06 & $\mathrm{~V}$ \\
\hline Speed & 7 & 9 & 8 & 4 & 14 & 12 & 10 & 13 & 11 & 12 & 46.44 & VII \\
\hline Spare parts Avail & 8 & 14 & 6 & 5 & 8 & 9 & 11 & 12 & 13 & 14 & 46.53 & VI \\
\hline Pick up & 3 & 7 & 5 & 14 & 6 & 3 & 18 & 16 & 15 & 13 & 43 & $\mathrm{X}$ \\
\hline After Sales Service & 6 & 8 & 9 & 8 & 11 & 5 & 14 & 16 & 10 & 13 & 45.64 & VIII \\
\hline Mileage & 9 & 6 & 7 & 10 & 13 & 2 & 2 & 13 & 19 & 19 & 43.75 & IX \\
\hline Total & 100 & 100 & 100 & 100 & 100 & 100 & 100 & 100 & 100 & 100 & & \\
\hline
\end{tabular}

Source: Survey data

Table 3. Relationship between socio-economic characteristics of e-bike users and their level of awareness

\begin{tabular}{llcccc}
\hline S. No & $\begin{array}{l}\text { Socio-Economic } \\
\text { Characteristics }\end{array}$ & $\begin{array}{c}\text { Calculated } \\
\text { Value }\end{array}$ & $\begin{array}{c}\text { Table } \\
\text { Value }\end{array}$ & $\begin{array}{c}\text { Degree of } \\
\text { freedom }\end{array}$ & Result \\
\hline 1. & Age & 1.010 & 7.815 & 3 & Insignificant \\
2. & Gender & 2.232 & 3.841 & 1 & Insignificant \\
3. & Marital Status & 1.004 & 3.841 & 1 & Insignificant \\
4. & Nature of Family & 2.232 & 3.841 & 1 & Insignificant \\
5. & Educational Status & 1.111 & 5.991 & 2 & Insignificant \\
6. & Occupation & 0.621 & 9.488 & 4 & Insignificant \\
7. & Annual Income & 1.808 & 7.815 & 3 & Insignificant \\
\hline Table value at 5\% level of significance & & & &
\end{tabular}

Table 4. Relationship between socio-economic characteristics of e-bike users and their level of satisfaction

\begin{tabular}{llcccc}
\hline S. No & $\begin{array}{l}\text { Socio-Economic } \\
\text { Characteristics }\end{array}$ & $\begin{array}{c}\text { Calculated } \\
\text { Value }\end{array}$ & $\begin{array}{c}\text { Table } \\
\text { Value }\end{array}$ & $\begin{array}{c}\text { Degree of } \\
\text { freedom }\end{array}$ & Result \\
\hline 1. & Age & 5.947 & 7.815 & 3 & Insignificant \\
2. & Gender & 0.541 & 3.841 & 1 & Insignificant \\
3. & Marital Status & 0.007 & 3.841 & 1 & Insignificant \\
4. & Nature of Family & 1.309 & 3.841 & 1 & Insignificant \\
5. & Educational Status & 0.697 & 5.991 & 2 & Insignificant \\
6. & Occupation & 0.616 & 9.488 & 4 & Insignificant \\
7. & Annual Income & 1.623 & 7.815 & 3 & Insignificant \\
\hline
\end{tabular}

Source: Computed from survey data

Table value at $5 \%$ level of significance 
socio-economic characteristics of E-Bike users and their level of awareness towards various features of E-Bikes.

From Table.4, it is found that the calculated values for all the socio-economic characteristics considered are less than the table values at $5 \%$ level of significance and the framed null hypotheses are accepted. Hence, it is concluded that there is no significant relationship between various socio-economic characteristics of E-Bike users and their level of satisfaction towards various features of E-Bikes.

For analyzing the problems faced by the E-Bike Users in the study area, Eleven Problems as exhibited in Table 5 have been taken into consideration.

It is inferred from Ranking Analysis that sample E-Bike users have ranked 'Poor Battery Life' as first with a mean score of 69.09, 'Slow Speed' as second with a mean score of 66.84 and 'Poor Mileage' as third with a mean score of 65.04, followed by 'Poor Pick Up', 'Not for Long Travel', 'High Purchase Cost', 'Longtime Recharge', 'Poor Look', 'Poor Sale Service,' 'High Recharge Cost' and 'Battery Pollution'. Hence, it can be concluded that the 'Poor Battery Life, 'Slow Speed' and 'Poor Mileage' are the major problems faced by the E-Bike users in the study area.

\section{Findings of the Study}

The following are the key findings of the study:

- Percentage Analysis has revealed that the majority of $56 \%$ of the sample E-Bike users had preferred "HeroElectric Bike.

- Garrett Ranking Analysis has disclosed that 'Smooth Driving' is the most important factor which influences the E-Bike users to select a particular brand of E-Bike and 'Poor Battery Life' is the most important problem faced by them.

- The Chi-square test has exposed that there is no significant relationship between various socio-economic characteristics of E-Bike users and their level of awareness and satisfaction towards various features of E-Bike.

\section{Suggestions of the Study}

Based on the findings of the study, some viable suggestions have been offered as follows:

- Manufacturers of E-Bikes should concentrate on improving the feature of 'Smooth Driving' in case of E-Bikes, so as to reap a surge in its sales.

- To overcome the problem of poor battery life faced by the E-Bike users, the manufacturers should come up with high-tech batteries that offer extended life time beyond two years.

- To increase the speed of E-Bikes, manufacturers can consider using 300 watt power motor instead of 250 watt power which offers a maximum speed of just 25 $\mathrm{km} / \mathrm{ph}$ only.

- To solve the problem of 'Poor Mileage' per charge, it is suggested that the Government should take steps to install charging point at petrol bunks, restaurants and departmental stores by providing financial assistance to the interested people. By doing so, the users can charge their battery and travel for further distances.

- The E-Bike manufacturing companies may also consider solar energy for E-Bikes that may support for long travel and reduce the charging time of the battery.

Table 5. Problems faced by the e-bike users: Ranking analysis

\begin{tabular}{|c|c|c|c|c|c|c|c|c|c|c|c|c|c|}
\hline \multirow[t]{3}{*}{ Factor } & \multicolumn{11}{|c|}{ Rank } & \multirow[t]{3}{*}{ Mean Score } & \multirow{3}{*}{ 華 } \\
\hline & 1 & 2 & 3 & 4 & 5 & 6 & 7 & 8 & 9 & 10 & 11 & & \\
\hline & 82 & 72 & 65 & 59 & 54 & 50 & 45 & 40 & 35 & 28 & 18 & & \\
\hline Slow speed & 13 & 41 & 17 & 12 & 2 & 14 & 1 & - & - & - & - & 66.84 & II \\
\hline Poor Pick Up & 22 & 15 & 17 & 15 & 16 & 1 & 13 & - & - & - & 1 & 63.91 & IV \\
\hline High purchase Cost & 1 & 1 & 18 & 5 & 14 & 12 & 14 & 14 & 1 & 11 & 9 & 46.7 & VI \\
\hline Battery pollution & 4 & - & 2 & 1 & 2 & 6 & 6 & 5 & 14 & 27 & 33 & 32.35 & $\mathrm{XI}$ \\
\hline Poor Battery Life & 27 & 21 & 25 & 20 & 7 & - & - & - & - & - & - & 69.09 & $\mathrm{I}$ \\
\hline Poor Mileage & 20 & 22 & 10 & 20 & 20 & 3 & 4 & 1 & - & - & - & 65.04 & III \\
\hline Not for long travel & 4 & - & 11 & 5 & 19 & 40 & 2 & 9 & 5 & 1 & 4 & 50.89 & $\mathrm{~V}$ \\
\hline Poor Sale Service & - & - & - & - & 1 & 11 & 14 & 26 & 30 & 4 & 14 & 36.88 & IX \\
\hline High Recharge cost & 5 & - & - & 10 & 1 & - & 20 & 3 & 15 & 26 & 20 & 36.87 & $\mathrm{X}$ \\
\hline Longtime Recharge & 1 & - & - & 1 & 16 & 11 & 17 & 17 & 25 & 12 & - & 42.11 & VII \\
\hline Poor Look & 3 & - & - & 11 & 2 & 2 & 9 & 25 & 10 & 19 & 19 & 37.32 & VIII \\
\hline Total & 100 & 100 & 100 & 100 & 100 & 100 & 100 & 100 & 100 & 100 & 100 & & \\
\hline
\end{tabular}




\section{Conclusion}

Global warming is a major concern and the whole world is moving towards environmentalism. It is felt that the gasoline vehicles are the major contributors for the environment pollution. Realizing this, the present study has been undertaken to analyse users' attitude towards E-Bikes in Erode district because of its social and economic importance to the study area. E-Bikes being environment friendly, its wide scale adoption in the study area can be achieved when the present E-Bike technology is upgraded. The government must initiate steps to provide increased subsidies to the E-Bike manufacturing companies so as to manufacture large number of E-Bikes with more utilities and advantages which can fulfill the expectation of the users.

In the prevailing scenario of increased environment pollution, the present research is a humble attempt to throw light on users' awareness and satisfaction level towards E-Bikes and also on the problems faced by the users towards E-Bike in Erode District of Tamil Nadu. The findings of the present study are not exclusive in nature, but are common to a majority of the E-Bike users in India. The study highlights the problems confronted by the E-Bike users of the study area, which can be solved and wide scale adoption of E-Bikes can be achieved only when innovative and upgraded technologies are introduced in the E-Bikes.

\section{References}

1. Bhatnagar Y. Assessment of consumer buying behaviour towards electric scooters in Punjab. Journal of Driving Innovation with Enterprise Simulation. 2006; 6(1):25-9.

2. Srivastava S. Customer perception on green brands of two wheelers and four wheelers in the state of Andhra Pradesh. Bilingual Journal of Humanities and Social Sciences. 2011 Jul; 2(1):25-30.

3. Hackbarth A. Consumer preferences for alternative fuel vehicles: A discrete choice analysis. Multidisciplinary Journal of Research in Engineering and Technology. 2012; 1(2):215-22.

4. Hausan. Influences of environmental consciousness and attitudes to transportation on electric vehicle purchase intentions. Proceedings of the Eastern Asia Society for Transportation Studies. 2013 Jul; 9(2):76-83.

\section{Other References}

1. Prasad B. The promotion of electric vehicles in India. Bilingual Journal of Humanities and Social Sciences. 2013 Dec; 4(2):26-32.

2. Chavan CS. Future of sustainable personal mobility solution in India. Case Studies Journal. 2014 Dec; 3(8):26-9.

3. Kitamura R. Modeling the choice of clean fuels and clean fuel vehicles. Bilingual Journal of Humanities and Social Sciences. 2014 Jul; 5(1):25-33. 